Available online at GSC Online Press Directory

GSC Biological and Pharmaceutical Sciences

e-ISSN: 2581-3250, CODEN (USA): GBPSC2

(RESEARCH ARTICLE)

\title{
Molecular diversity of multi-resistant and extended-spectrum beta lactamase- producing Escherichia coli from door handles in Lafia, central Nigeria
}

\author{
Tsaku Paul Alumbugu 1, ${ }^{*}$, Ibrahim Taibat ${ }^{2}$, Nkene Istifanus Haruna ${ }^{1}$, Abimiku Rejoice Helma ${ }^{1}$, Ishaleku \\ David ${ }^{1}$, Pennap Grace ${ }^{1}$ and Ngwai Yakubu Boyi ${ }^{1}$
}

${ }^{1}$ Department of Microbiology, Nasarawa State University, Keffi, Nigeria.

${ }^{2}$ Department of Science Laboratory Technology, Nasarawa State University, Keffi, Nigeria.

Publication history: Received on 18 April 2019; revised on 10 July 2019; accepted on 13 July 2019

Article DOI: https://doi.org/10.30574/gscbps.2019.8.1.0074

\begin{abstract}
Human hands have been implicated as a major source of dissemination of pathogenic microorganisms through fomites. This study investigated the diversity of ESBL-producing in E. coli isolates from door handles using restriction fragment length polymorphism (RFLP). An occurrence of $77(19.25 \%)$ of $E$. coli out of 400 samples was recovered from different locations. The study of antibiotics resistance showed that ampicillin, ceftazidime, and streptomycin were predominantly resistant. Multiple antibiotics resistance index of $\geq 0.3$ was recorded in $73(94.81 \%)$ of the isolates. A total of 40 resistant phenotypes were observed in this study, with AMP-AUG-CAZ-CRO-S-CIP-SXT-TE-C being the commonest. Twenty isolates were characterised as Multidrug resistant (MDR) phenotypes, followed by, pan drug resistance (PDR) and extensive resistance (XDR) phenotypes recorded in 12 and 8 isolates respectively. Thirty-six (36) ESBL-producers were identified out of which 14 harboured bla

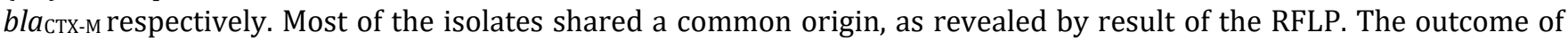
this study suggests the need for improved personal hygiene and the need for all stakeholders to be proactive in curtailing the spread of resistant pathogens.
\end{abstract}

Keywords: Escherichia coli; Extended-spectrum beta-lactamase; bla $a_{T E M}$; bla ${ }_{S H V}$; bla $a_{C T X-M ;}$ Restriction fragment length polymorphism

\section{Introduction}

Escherichia coli (E. coli) are Gram-negative, facultative anaerobic, bacilli (rod-shaped) which constitutes a major microflora of the lower intestines of warm-blooded organisms [1, 2]. Most strains are reportedly non-pathogenic, with some beneficial aspects such as synthesis of vitamins $\mathrm{B}_{12}$ and $\mathrm{K}$ within the hosts [3, 4], and preventing colonization of the intestine by pathogenic microbes $[5,6]$. Nonetheless, some pathogenic strains have also been reported and are capable of causing serious food poisoning in their hosts, and are occasionally responsible for product recall due to food contamination [7,8]. Faecal-oral transmission is the major route through which pathogenic strains of the bacterium cause disease.

The microorganism is capable of survival on inanimate surfaces for a limited time period, which makes them suitable indicators to test environmental samples for faecal contamination [9, 10]. Recent research has observed environmentally persistent E. coli which can survive for extended periods outside of a host [11]. Cephalosporins, particularly the third and fourth generation cephalosporins are used for treatment of infections caused by enterobacteriaceae such as E. coli [12]. Extended spectrum or third generation cephalosporins were introduced into clinical use in the early 1980s to offer effective therapy principally for infections caused by multidrug resistant

\footnotetext{
${ }^{*}$ Corresponding author

E-mail address: tsakupaul@gmail.com
} 
Enterobacteriaceae [13]. Resistance to cephalosporin has emerged globally and numerous types of ESBLs have been detected in several bacterial organisms [14]. Ghafourian et al. [15] defined ESBL as "enzymes produced by certain bacteria that are able to hydrolyse extended spectrum cephalosporin. They are therefore effective against beta-lactam antibiotics such as ceftazidime, ceftriaxone, cefotaxime and oxyiminomonobactam." E. coli can become resistant to extended spectrum cephalosporins by mutational overproduction of AmpC and/or by expression of acquired ESBLs. The latter emerged in the 1980s as derivatives of TEM (named after the patient Temoneira) and Sulfhydryl Reagent Variable (SHV) enzyme types [16].

About 300 to 600 different ESBL variants have been Reported [17, 18, 14], with TEM and SHV as the most common variants. Whereas the $C T X-M$ variant have continued to emerge over the past decade, and are now the most frequently reported aside TEM and SHV [19]. Since ESBLs are normally encoded by genes located on different transferable genetic elements, a diversity of epidemiological situations has been documented, ranging from sporadic cases to large outbreaks [20]. Moreover, ESBL-producing strains are often resistant to antibiotics of other classes (such as, sulfonamides, aminoglycosides, and quinolones) which complicate available treatment strategies in many hospitalized patients $[21,22]$. This study therefore determines the Molecular Diversity of ESBL-producing E. coli from door handles in Lafia, Central Nigeria.

\section{Material and methods}

The study was conducted in Federal University, Lafia (FUL) and Nasarawa State Polytechnic, Lafia (NPL). Lafia is a town in central Nigeria. It is the capital city of Nasarawa State and has an approximate population of 330,712 inhabitants according to the 2006 census results. It is the largest town in Nasarawa state.

\subsection{Sample collection}

A cross-sectional study was carried out following stratified random sampling technique. A total of 400 door handles were sampled (200 each from the two institutions) using sterile swab sticks immersed in $0.85 \%$ sterile normal saline solution.

\subsection{Isolation and identification of Escherichia coli}

Samples were cultured on Levine Eosin Methylene Blue (EMB) Agar plates and incubated at $37{ }^{\circ} \mathrm{C}$ for 24 hours. The plates were observed after 24 hours incubation; greenish metallic sheen indicates the presence of Escherichia spp [23]. API 20E (Biomerieux ${ }^{\mathrm{TM}}$ ) kit was used for identification of E. coli following manufacturer's instructions.

\subsection{Antibiotics susceptibility test}

The antibiotics susceptibility test of the E. coli isolates was carried out using Kirby-Baeur disk diffusion method. The antibiotic disks were firmly placed on the sterile Muiller Hinton Agar (MHA) plates seeded with test organisms, standardised to 0.5 McFarland's turbidity standard and incubated at $37{ }^{\circ} \mathrm{C}$ for 24 hours. Diameter of zones of inhibition was then measured to the nearest millimetre and reported in accordance with the antimicrobial susceptibility breakpoint of CLSI [24].

\subsection{Determination of Multiple Antibiotic Resistance (MAR) Index}

The MAR Index was determined according to the method of Krumperman [25] and Paul et al. [26]. From the result of the antibiotic susceptibility test, MARI was calculated as:

$$
\text { MAR Index }=\frac{\text { No. of antibiotics to which isolate is resistant }}{\text { Total no. of antibiotics tested }}
$$

\subsection{Phenotypic Detection of ESBL}

ESBL production was detected by the conventional Double Disc Synergy Test (DDST) using ceftazidime (30 $\mu$ g) and cefotaxime discs $(30 \mu \mathrm{g})$ with or without clavulanic acid $(10 \mu \mathrm{g})$ as recommended by the CLSI. An increase of $\geq 5 \mathrm{~mm}$ in the inhibition zones of either cephalosporin in combination with clavulanic acid compared to the cephalosporin alone was interpreted as ESBL positive [24]. 


\subsection{DNA extraction}

Bacterial culture was inoculated into Luria-Bertani (LB) broth and incubated at $37{ }^{\circ} \mathrm{C}$ for 8 hours. Five millilitres of the LB broth culture of the containing the bacterial isolates was spun at $14000 \mathrm{rpm}$ for 3 min. The cells were resuspended in $500 \mu \mathrm{l}$ of normal saline and heated at $95{ }^{\circ} \mathrm{C}$ for $20 \mathrm{~min}$ in the heating chamber. The heated bacterial suspension was cooled on ice and spun for $3 \mathrm{~min}$ at $14000 \mathrm{rpm}$. The supernatant containing the DNA was transferred to a $1.5 \mathrm{ml}$ microcentrifuge tubes and stored at $-20^{\circ} \mathrm{C}$ for other subsequent experimentations.

\subsection{DNA Quantification}

The extracted genomic DNA was quantified using the NanoDrop 1000 spectrophotometer by placing a drop (approximately $2 \mu \mathrm{l}$ ) on the sample space and analysed using the NanoDrop 1000 software.

\subsection{Amplification of bla TEM, $_{\text {bla }}$ SHV, and bla CTX-M $_{\text {genes }}$}

The bla ${ }_{T E M}, b_{S H V}$, and bla $_{C T X-M}$ genes were amplified using specific primers (Table 1) on thermal cycler (Bio-RAD) at a final volume of $25 \mu \mathrm{l}$ for 35 cycles. The PCR mix included: X2 Dream Taq master mix (Thermo Scientific ${ }^{\mathrm{TM}}$ ), the primers at a concentration of $0.2 \mathrm{M}$ and the extracted DNA as template. The PCR conditions were as follows: Initial denaturation, $95^{\circ} \mathrm{C}$ for 5 minutes; denaturation, $95^{\circ} \mathrm{C}$ for 30 seconds; annealing, $52{ }^{\circ} \mathrm{C}$ for 30 seconds; extension, 72 ${ }^{\circ} \mathrm{C}$ for 30 seconds for 35 cycles and final extension, $72^{\circ} \mathrm{C}$ for 5 minutes. The product was resolved on a $1.5 \%$ agarose gel at $120 \mathrm{~V}$ for 20 minutes and visualized on a UV transilluminator.

\subsection{Molecular typing of the isolates using Restriction Fragment Length Polymorphism (RFLP) analyses}

The method of Lacher et al. [27] was adopted for RFLP to identify E. coli variants. To achieve species-specific discriminatory patterns, a $5 \mu \mathrm{l}$ aliquot of PCR products was digested with $10 \mathrm{U} / \mu \mathrm{l}$ of ECO471 (AvalI - ThermoFisher Scientific) in a final volume of $25 \mu$ la $37{ }^{\circ} \mathrm{C}$ for 6 hours. The restriction fragments were separated on $2 \%$ agarose gel electrophoresis in TBE buffer for about 30 minutes at $120 \mathrm{~V}$ and visualized by staining with $0.5 \mu \mathrm{g} / \mathrm{ml}$ of ethidium bromide.

Table 1 List of primers for ESBL genes

\begin{tabular}{llll}
\hline Primer & Sequence (5' - 3') & Amplicon length(bp) & Reference \\
\hline bla $_{\mathrm{SHV}}$ & F: CGCCTGTGTATTATCTCCCT & 401 & {$[28]$} \\
& R: CGAGTAGTCCACCAGATCCT & & \\
bla $_{\mathrm{CTX}-\mathrm{M}}$ & F: CGCTTTGCGATGTGCAG & $550-600$ & {$[29]$} \\
& R: ACCGCGATATCGTTGGT & & \\
bla $_{\mathrm{TEM}}$ & F: TTTCGTGTCGCCCTTATTCC & 980 & {$[28]$} \\
\multirow{2}{*}{$16 \mathrm{~s}$ rRNA } & R: ATCGTTGTCAGAAGTAAGTTGG & & \\
& F: AGAGTTTGATCMTGGCTCAG & 27 & {$[30]$} \\
& R: CGGTTACCTTGTTACGACTT & 1492 & \\
\hline
\end{tabular}

\section{Results}

In this study, a total $77(19.25 \%)$ E. coli isolates were recovered from 400 door handles sampled in two different tertiary institutions in Lafia, Nasarawa State, Nigeria. The two institutions are Federal University, Lafia and Nasarawa State Polytechnic, Lafia where the isolation rates were 32(16.00\%) and 45(22.50\%) respectively (Table 2).

Table 2 Isolation of $E$. coli from door handles in Lafia

\begin{tabular}{lll}
\hline Location & No. of Samples & No. of Isolates (\%) \\
\hline FUL & 200 & $32(16.00)$ \\
NPL & 200 & $45(22.50)$ \\
Total & 400 & $77(19.25)$ \\
\hline \multicolumn{3}{c}{ Key: FUL = Federal University, Lafia } \\
& NPL = Nasarawa State Polytechnic, Lafia
\end{tabular}

The antibiotics susceptibility/resistance profile of the isolated bacteria (as shown in Table 3) indicates that streptomycin $68(88.31 \%)$ was the most resistant of the tested antibiotics. Gentamicin $13(16.88 \%)$ was however the least resistant among the test antibiotics. 
Table 3 Antibiotics susceptibility profile of $E$. coli isolates from door handles in Lafia

\begin{tabular}{lllll}
\hline Antibiotics & \multicolumn{3}{l}{$\begin{array}{l}\text { Disc Content } \\
(\boldsymbol{\mu g})\end{array}$} & \multicolumn{2}{l}{ NO. (\%) Resistant } \\
\cline { 3 - 5 } & 10 & $30(93.75)$ & $35(77.78)$ & $65(84.42)$ \\
& Ampicillin (AMP) & $28(87.50)$ & $22(48.89)$ & $50(64.94)$ \\
Augmentin (AUG) & 30 & $30(93.75)$ & $23(51.11)$ & $53(68.83)$ \\
Ceftazidime (CAZ) & 30 & $12(37.50)$ & $11(24.44)$ & $23(29.87)$ \\
Ceftriaxone (CRO) & 30 & $28(87.50)$ & $40(88.89)$ & $68(88.31)$ \\
Streptomycin (S) & 10 & $5(15.63)$ & $7(15.56)$ & $13(16.88)$ \\
Gentamicin (CN) & 10 & $13(40.63)$ & $23(51.11)$ & $36(46.75)$ \\
Ciprofloxacin (CIP) & 5 & $27(84.38)$ & $34(75.56)$ & $61(79.22)$ \\
Sulphamethoxazole/Trimethoprim (SXT) & $23.75 / 1.25$ & $29(90.63)$ & $38(84.44)$ & $67(87.01)$ \\
Tetracycline (TE) & 30 & $14(43.75)$ & $22(48.89)$ & $36(46.75)$ \\
Chloramphenicol (C) & 30 & &
\end{tabular}

Table 4 Resistant phenotypes of E. coli isolates from door handles in Lafia

\begin{tabular}{|c|c|c|c|c|c|}
\hline \multirow[t]{2}{*}{$\mathbf{S} / \mathbf{N}$} & \multirow{2}{*}{ Phenotype } & \multicolumn{2}{|c|}{ No. of Isolates } & \multicolumn{2}{|r|}{ Class of resistance } \\
\hline & & FUL & NPL & TOTAL & \\
\hline 1 & AMP-C & - & 1 & 1 & MDR \\
\hline 2 & S-TE & - & 1 & 1 & MDR \\
\hline 3 & SXT-TE & - & 1 & 1 & MDR \\
\hline 4 & S-SXT-TE & - & 1 & 1 & MDR \\
\hline 5 & AMP-S-TE & 1 & - & 1 & MDR \\
\hline 6 & S-CIP-TE & - & 1 & 1 & MDR \\
\hline 7 & AMP-AUG-CAZ-TE & 1 & - & 1 & MDR \\
\hline 8 & AMP-S-TE-C & 1 & - & 1 & MDR \\
\hline 9 & CAZ-S-SXT-TE & 1 & 1 & 2 & MDR \\
\hline 10 & AMP-AUG-S-SXT & - & 1 & 1 & MDR \\
\hline 11 & AMP-S-SXT-TE & - & 4 & 4 & MDR \\
\hline 12 & AMP-S-CIP-TE & - & 1 & 1 & MDR \\
\hline 13 & CAZ-S-SXT-TE & - & 1 & 1 & MDR \\
\hline 14 & AUG-CAZ-S-SXT-TE & 1 & 1 & 2 & MDR \\
\hline 15 & AMP-AUG-CAZ-SXT-C & - & 1 & 1 & MDR \\
\hline 16 & AMP-AUG-S-SXT-TE & - & 1 & 1 & MDR \\
\hline 17 & AMP-CAZ-S-SXT-TE & - & 1 & 1 & MDR \\
\hline 18 & AMP-S-CN-TE-C & - & 1 & 1 & MDR \\
\hline 19 & AMP-S-SXT-TE-C & - & 1 & 1 & MDR \\
\hline 20 & CAZ-S-SXT-TE-C & - & 1 & 1 & MDR \\
\hline 21 & AMP-AUG-CAZ-S-SXT-TE & 7 & - & 7 & PDR \\
\hline 22 & AMP-AUG-CAZ-S-CIP-SXT & 1 & 1 & 2 & PDR \\
\hline 23 & AMP-AUG-CAZ-CRO-SXT-C & 2 & 1 & 3 & PDR \\
\hline 24 & AMP-AUG-S-CN-CIP-SXT & - & 1 & 1 & PDR \\
\hline 25 & AMP-S-CN-CIP-SXT-TE & - & 2 & 2 & PDR \\
\hline 26 & AMP-S-CIP-SXT-TE-C & - & 1 & 1 & PDR \\
\hline 27 & CAZ-S-CIP-SXT-TE-C & - & 1 & 1 & PDR \\
\hline 28 & AMP-AUG-CAZ-S-CN-TE-C & - & 1 & 1 & PDR \\
\hline 29 & AMP-CAZ-S-CIP-SXT-TE-C & - & 1 & 1 & PDR \\
\hline 30 & AMP-AUG-CAZ-CRO-S-SXT-TE & 1 & - & 1 & PDR \\
\hline 31 & AMP-AUG-CAZ-S-CIP-TE-C & 1 & - & 1 & PDR \\
\hline 32 & AMP-AUG-CAZ-S-CIP-SXT-TE & 1 & 4 & 5 & PDR \\
\hline 33 & AMP-AUG-CAZ-CRO-S-CIP-SXT-TE & 3 & 2 & 5 & $\mathrm{XDR}$ \\
\hline 34 & AMP-AUG-CAZ-CRO-S-CN-SXT-TE & 2 & - & 2 & $\mathrm{XDR}$ \\
\hline 35 & AMP-AUG-CAZ-S-CN-CIP-TE-C & 1 & - & 1 & XDR \\
\hline 36 & AMP-AUG-CAZ-S-CN-SXT-TE-C & 3 & - & 3 & XDR \\
\hline 37 & AMP-AUG-CRO-S-CN-SXT-TE-C & - & 1 & 1 & XDR \\
\hline 38 & AMP-AUG-CAZ-CRO-S-SXT-TE-C & 1 & - & 1 & XDR \\
\hline 39 & AMP-AUG-CAZ-CRO-S-CIP-SXT-TE-C & 2 & 7 & 9 & $\mathrm{XDR}$ \\
\hline 40 & AMP-AUG-CAZ-CRO-S-CN-CIP-SXT-TE-C & 2 & 1 & 3 & $\mathrm{XDR}$ \\
\hline
\end{tabular}


Forty (40) resistant phenotypes was recorded in this study out of which 20 were Multidrug resistant (MDR) phenotype, 12 were Pan drug resistant (PDR) and 8 Extensively resistant (XDR) phenotypes (Table 4).

The Multiple Antibiotics Resistance Index (MARI) indicates that out of the 77 total E. coli isolates, only 1(1.30) had 0.00 MARI; implying susceptibility to all tested antibiotics. The remaining 76 isolates had MAR Indices $\geq 0.2$ which implies that they were all resistant to at least 2 of the test antibiotics (Table 5).

Table 5 Multiple Antibiotics Resistance Index (MARI) of E. coli isolates from door handles in Lafia

\begin{tabular}{llll}
\hline \multirow{2}{*}{ MARI } & \multicolumn{4}{l}{ NO. (\%) OF ISOLATES } \\
\cline { 2 - 4 } & FUL (n=32) & NPL (n=45) & $\begin{array}{l}\text { TOTAL } \\
\text { (n=77) }\end{array}$ \\
\hline 0.00 & 0 & $1(2.22)$ & $1(1.30)$ \\
0.20 & 0 & $3(6.67)$ & $3(3.90)$ \\
0.30 & $1(3.13)$ & $2(4.44)$ & $3(3.90)$ \\
0.40 & $3(9.38)$ & $8(17.78)$ & $11(14.29)$ \\
0.50 & $1(3.13)$ & $7(15.56)$ & $8(10.40)$ \\
0.60 & $10(31.25)$ & $7(15.56)$ & $17(22.08)$ \\
0.70 & $3(9.38)$ & $6(13.33)$ & $9(11.69)$ \\
0.80 & $10(31.25)$ & $5(11.11)$ & $15(19.48)$ \\
0.90 & $2(6.25)$ & $6(13.33)$ & $8(10.39)$ \\
1.00 & $2(6.25)$ & $0(0.00)$ & $2(2.60)$ \\
\hline
\end{tabular}

Figures 1, 2 and 3 are gel pictures of TEM, SHV and CTX-M genes extracted from E. coli isolates from door handles in Lafia

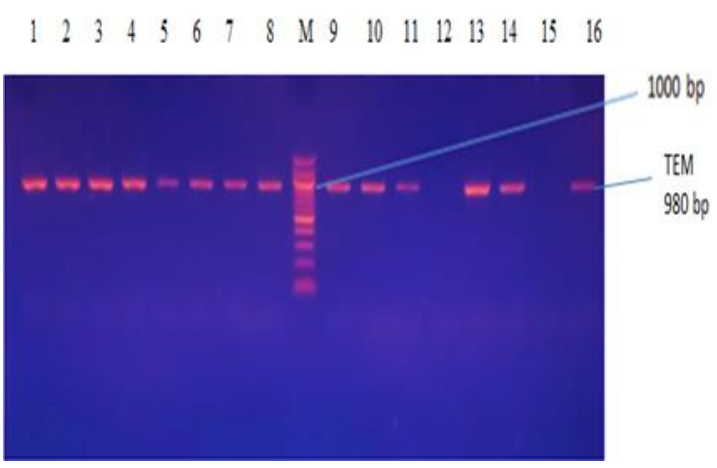

Figure 1 Agarose gel electrophoresis of the amplified bla TEM genes from the ESBL producing E. coli isolates

Lanes 1-11, 13-14 and 16 represent the bla ТЕ bands. Lane M represents the $100 \mathrm{bp}$ molecular marker, while other lanes show no bands.

$\begin{array}{lllllllllllllllll}1 & 2 & 3 & 4 & M & 5 & 6 & 7 & 8 & 9 & 10 & 11 & 12 & 13 & 14 & 15 & 16\end{array}$

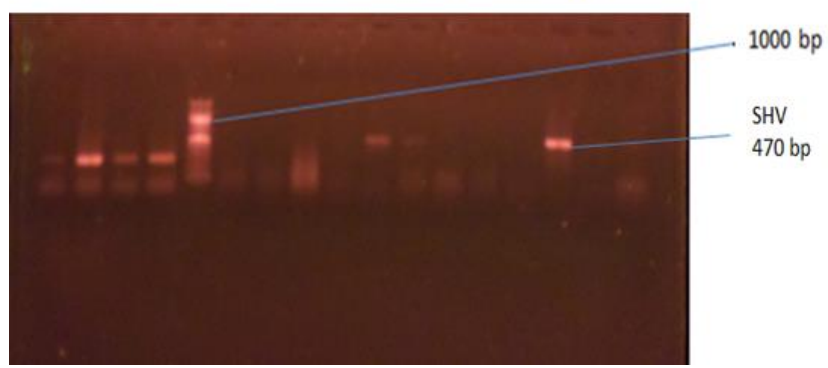

Figure 2 Agarose gel electrophoresis of the amplified blashv genes from the ESBL producing E. coli isolates. 
Lanes 2-4, 9 and 14 represent the bla $\mathrm{SHv}_{\mathrm{H}}$ bands. Lane $\mathrm{M}$ represents the $100 \mathrm{bp}$ molecular marker, while other lanes show no bands.

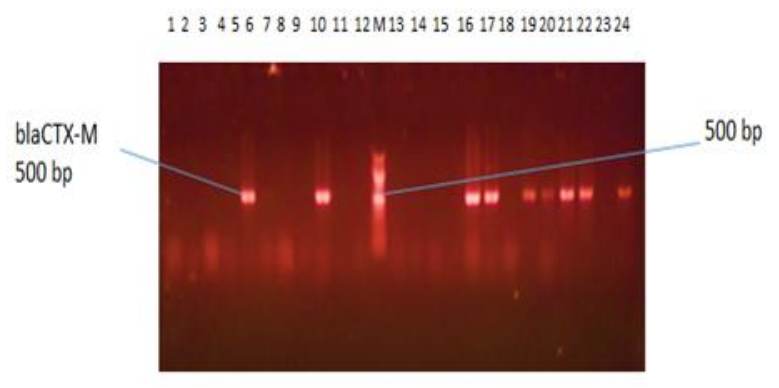

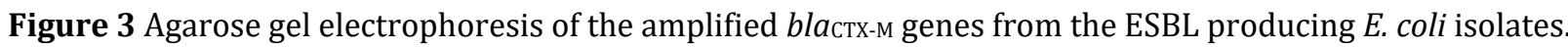

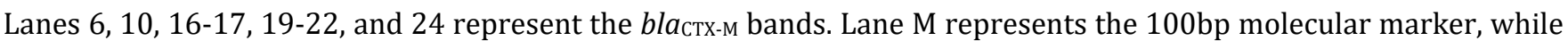
other lanes show no bands.

\section{Discussion}

In this study, a significant numbers of $E$. coli isolates was recovered from the door handles studied, which indicates low levels of hygiene practices in the locality of the survey. A total of 77(19.25\%) E. coli was isolated from 400 door handles sampled in this study. From the two different locations (tertiary institutions) door handles sampled, the isolates obtained were 32(16.00\%), and 45(22.50\%), representing Federal University Lafia, and Nasarawa State Polytechnic Lafia respectively.

These results should stimulate drastic public health concern, since the presence of $E$. coli on door handles suggests the possibility of contamination from faecal sources. E. coli has frequently been isolated from door handles and several other handy surfaces such as bannisters, crevices, and toilet knobs globally [4, 31- 35]. Similarly, enterobacteriaceae such as Salmonellae, Enterobacter, Proteus, Klebsiella, Citrobacter, Providencia and Yersinia have also been isolated from door handles and other environmental surfaces [31-32, 35-36].

The Antibiotics susceptibility/resistance assessment of the E. coli isolates from door handles in this study shows varying forms of antimicrobial resistance to the antibiotics studied. In all, (98.70\%) of the isolates were resistant to two or more of the test antibiotics (Table 4), which corroborates the reports of Ajayi and Ekozien, [35] and Opere et al. [37]. This observation suggests that the E. coli isolates in this study may probably have originated from an environment where antibiotics were often used indiscriminately [38]. Broad-spectrum antibiotics are sometimes reported to be given in place of narrow-spectrum antibiotics as a substitute for culture and sensitivity testing, with the consequent risk of selection of antibiotic-resistant mutants [25, 39-41].

This study highlights a highly diverse antibiotics resistance rates among the E. coli isolates. The general order of antibiotics resistance in the study was: streptomycin $(88.31 \%)>$ Tetracycline $(87.01 \%)>$ ampicillin $(84.42 \%)>$ cotrimoxazole $(79.22 \%)>$ ceftazidime $(68.83 \%)>$ augmentin $(64.94 \%)>$ chloramphenicol $(46.75 \%)=$ ciprofloxacin $(46.75 \%)>$ ceftriaxone $(29.87 \%)>$ gentamicin $(16.88 \%)$. Similar to previous reports by Tsaku et al. [4] and Mohammed et al. [36] with similar antibiotics, this study also confirms gentamicin to be more effective than all the tested antibiotics. The effectiveness of gentamicin is possibly due to inaccessibility to the antibiotics and the parenteral routes of administering them. Likewise the massive resistance to antibiotics such as tetracycline and streptomycin could be attributed to their inability to reach target site in the bacteria. The findings from this present study agrees with the work reported by Okonko et al. [38], who reported high bacterial isolates resistance to ampicillin, augmentin and co-trimoxazole (60 to 100\%). Other researchers have reported bacterial isolates obtained from public surfaces to be resistant to co-trimoxazole [31- 35].

Antibiotic resistance of $E$. coli isolated from door handles in this study may be a reflection of the prevailing resultant effects of self-medication of antibiotics in the schools investigated and the surrounding environments.

A total of forty (40) resistant phenotypes were observed in this study. The most common resistant phenotype was AMP-AUG-CAZ-CRO-S-CIP-SXT-TE-C which appeared 9 times. Multidrug resistant (MDR) phenotypes was the most 
popular with 20 appearances, whereas, pan drug resistance (PDR) and extensive resistance (XDR) was recorded in 12 and 8 phenotypes respectively. Such multi-antibiotic resistance has important implications for the empiric therapy of infections caused by E. coli and other enterobacteriaceae $[42,43]$. It has been well documented that Gram negative bacilli harbour series of antibiotic resistance genes like transposons or integrons and $\mathrm{R}$ plasmids which can be transferred to other bacteria horizontally [44- 47].

Thirty six (46.75\%) of the bacterial isolates were confirmed ESBL producers from the two institutions studied. This result agrees with several reports on the subject area; for example, 48\% ESBL-producing E. coli was reported from south-east Nigeria [48]. Kamel et al. [49], also reported 50.88\% ESBL-producing E. coli from Egypt, with similar reports from Oyo state, south-western Nigeria [50], Tunisia [51], Morocco [52], and Sudan [53].

An important consequence of these resistances is that many bacterial diseases that could be treated with inexpensive antibiotics, has recently been made more expensive and less successful by the emergence and spread of resistant organisms [38, 54]. However, these multi-antibiotic resistances observed among some of the test E. coli isolates from door handles in this study has increased the growing therapeutic failure problem of infectious bacteria that account for most of Africa's disease burden, including respiratory and diarrhoeal diseases [54].

The molecular screening for bla $a_{\mathrm{TEM}}, b l a_{\mathrm{SHV}}$, and $b_{\mathrm{CTX} \text {-м }} \mathrm{ESBL}$ genes revealed that 14 out of the 77 isolates harboured bla $a_{\mathrm{TEM}}$, while 5 and 9 were carriers of bla $a_{\mathrm{SHV}}$ and bla $_{\mathrm{CTX}-\mathrm{M}}$ respectively. This result unlike most previous reports which indicated that bla that bla тем was most predominant, followed by bla

These results are of significant public health importance considering the fact that ESBLs are plasmid-mediated and are usually associated with transposons and insertion sequences [58], which imply that they are easily transmissible to other potential pathogenic microbes of the same or different species. The exchange of plasmids between bacterial cells and the integration of resistance genes into specialized genetic elements play a major role in acquisition and dissemination of antibiotic resistance genes among bacteria isolates [59- 63 ].

Molecular typing of the isolates from the different institutions using restriction enzymes, Eco471 (AvalI), revealed similar pattern of cuts; which signifies that the isolates are most probably of the same strain or from the same source. This is an indication of the mobility of the microbes across the geographical location or even further beyond.

This research report is a timely call on all public health stakeholders to be on guard in order to prevent the continuous spread of multiple antibiotics resistant pathogens.

\section{Conclusion}

There is an occurrence of $19.25 \%$ E. coli contamination on door handles in Federal University, Lafia and Nasarawa State Polytechnic, Lafia, and 76 out of 77 the isolates are resistant to 2 or more test antibiotics. The most common resistant phenotype was AMP-AUG-CAZ-CRO-S-CIP-SXT-TE-C which appeared 9 times; with 20 MDR phenotypes followed by, PDR (12) and XDR (8).Thirty six (36) ESBL-producers were identified out of 77 E. coli isolates. Fourteen (14) isolates harboured bla Most of the isolates shared a common origin, as revealed by result of the RFLP.

\section{Compliance with ethical standards}

\section{Acknowledgments}

The researchers acknowledge the contribution of Professor Tatfeng Mirabeu of the Molecular Biology Laboratory, College of Health Sciences, Niger Delta University, Nigeria.

\section{Disclosure of conflict of interest}

Authors have declared that no competing interests exist. 


\section{References}

[1] Eckburg PB, Bik EM, Bernstein CN, Purdom E, Dethlefsen L and Sargent M. (2005). Diversity of the human intestinal microbial flora. Science, 308 (5728), 1635-8.

[2] Tenaillon O, Skurnik D, Picard B and Denamur E. (2010). The population genetics of commensal Escherichia coli. Nature Reviews Microbiology, 8(3), 207-217.

[3] Bentley R and Meganathan R. (1982). Biosynthesis of vitamin K (menaquinone) in bacteria. Microbiological Reviews, 46 (3), 241-80.

[4] Tsaku PA, Ehinmidu JO and Mohammed SA. (2017). Antibiotic Susceptibility and Plasmid Profile of Escherichia coli from Door Handles in Two Tertiary Institutions in Nasarawa State, Nigeria. Journal of Advances in Microbiology, 3 (3), 1-13.

[5] Hudault S, Guignot J and Servin AL. (2001). Escherichia coli strains colonising the gastrointestinal tract protect germfree mice against Salmonella typhimurium infection. Gut, 49 (1), 47-55.

[6] Reid G, Howard J and Gan BS. (2001). Can bacterial interference prevent infection? Trends in Microbiology, 9 (9), 424-428.

[7] Vogt RL and Dippold L. (2005). Escherichia coli 0157:H7 outbreak associated with consumption of ground beef, June-July 2002. Public Health Reports (Washington, DC: 1974), 120 (2), 174-8.

[8] CDC (2012). Escherichia coli. Centers for Disease Control and Prevention, National Center for Emerging and Zoonotic Infectious Diseases.

[9] Feng P, Weagant S and Grant M. (2002). Enumeration of Escherichia coli and the Coliform Bacteria. Bacteriological Analytical Manual (8th ed.). FDA/Center for Food Safety \& Applied Nutrition, Retrieved 200701-25.

[10] Thompson J and Andrea R. (2007). E. coli Thrives in Beach Sands. Live Science.

[11] Ishii S and Sadowsky MJ. (2008). Escherichia coli in the Environment: Implications for Water Quality and Human Health. Microbes and Environments, 23 (2), 101-8.

[12] Raji MA, Jamal W, Ojemhen O and Rotimi VO. (2013). Point-surveillance of antibiotic resistance in Enterobacteriaceae isolates from patients in a Lagos Teaching Hospital, Nigeria. Journal of Infection and Public Health, 6, 431-7.

[13] Ahmed OI, El-Hady SA, Ahmed TM and Ahmed IZ. (2013). Detection of bla SHV and bla CTX-M genes in ESBL producing Klebsiella pneumoniae isolated from Egyptian patients with suspected nosocomial infections. The Egyptian Journal of Medical Human Genetics, 14, 277-283.

[14] Delgado YC, Barrigas PT, Astutilloa SO, Jaramillo AP and Ausili A. (2016). Detection and molecular characterization of b-lactamase genes in clinical isolates of Gram-negative bacteria in Southern Ecuador. Brazilian Journal of Infectious Diseases, 20(6), 627-30.

[15] Ghafourian S, Sadeghifard N, Soheili S and Sekawi Z. (2015). Extended Spectrum Beta-lactamases: Definition, Classification and Epidemiology. Current Issues in Molecular Biology, 17, 11-22.

[16] Gutkind GO, Di Conza J, Power P and Radice M. (2013). Beta-lactamase mediated resistance: a biochemical, epidemiological and genetic overview. Current Pharmaceutical Design, 19, 164-208.

[17] Paterson DL and Bonomo R. (2005). Extended-spectrum beta-lactamases: a clinical update. Clinical Microbiology Review, 18, 657-86.

[18] Shaikh S, Jamale F, Shazi S, Syed M, Danish R and Mohammad AK. (2015). Antibiotic resistance and extended spectrum beta-lactamases: Types, epidemiology and treatment. Saudi Journal of Biological Sciences, 22, 90101.

[19] Bonnet R. (2004). Growing group of extended-spectrum beta lactamases: the CTX-M enzymes. Antimicrobial Agents and Chemotherapy, 48, 1-14.

[20] Canton R, Novais A and Valverde A. (2008). Prevalence and spread of extended-spectrum beta-lactamaseproducing Enterobacteriaceae in Europe. Clinical Microbiology Infections, 14, 144-53. 
[21] Fang H, Ataker F, Hedin G and Dornbusch K. (2008). Molecular epidemiology of extended-spectrum betalactamases among Escherichia coli isolates collected in a Swedish hospital and its associated health care facilities from 2001 to 2006. Journal of Clinical Microbiology, 46, 707-712.

[22] Lina TT, Khajanchi BK, Azmi IJ, Islam MA, Mahmood B, Akter M, Banik A, Alim R, Navarro A, Perez G, Cravioto A and Talukder KA. (2014). Phenotypic and Molecular Characterization of Extended-Spectrum Beta-Lactamase Producing Escherichia coli in Bangladesh. PLoS ONE, 9(10), e108735.

[23] Cheesbrough M. (2000). Microbiological Tests. In: Cheesbrough, M., Ed., District Laboratory Practice in Tropical Countries, Part II, Low Priced Edition, Cambridge University Press, Cambridge, 105-130.

[24] Clinical and Laboratory Standards Institute (2012). Performance Standards for Antimicrobial Susceptibility Testing. CLSI 22nd Informational Supplement M100-S22. Wayne, PA, USA.

[25] Krumperman PH. (1983). Multiple antibiotic indexing Escherichia coli to identifying risk sources of faecal contamination of foods. Applied Environmental Microbiology, 46, 165-170.

[26] Paul S, Bezbarauh RL, Roy MK and Ghosh AC. (1997). Multiple antibiotic resistant index and its reversion in Pseudomonas aeroginosa. Letters of Applied Microbiology, 24, 109-171.

[27] Lacher DW, Steinsland H and Whittam TS. (2006). Allelic subtyping of the intimin locus (eae) of pathogenic Escherichia coli by fluorescent RFLP. FEMS Microbiology Letters, 261, 80-7.

[28] Melika S, Reza M and Noor A. (2014). Molecular identification of TEM and SHV extended spectrum $\beta$-lactamase in clinical isolates of Acinetobacter baumannii from Tehran hospitals. Journal of Genes, Microbes and Immunity, $14,1-9$.

[29] Afzali H, Firoozeh F, Amiri A, Moniri R and Zibaei M. (2015). Characterization of CTX-M-Type Extend-Spectrum $\beta$-Lactamase Producing Klebsiella spp. in Kashan, Iran. Jundishapur Journal of Microbiology, 8(10), e27967.

[30] Jiang H, Dong H, Zhang G, Yu B, Chapman LR and Fields MW. (2006). Microbial diversity in water and sediment of Lake Chaka, an athalassohaline lake in northwestern China. Applied and Environmental Microbiology, 72(6), $3832-45$.

[31] Samy SA and Hamdy ME. (2012). Pathogenic Bacteria Associated with Different Public Environmental Sites in Mecca City. Open Journal of Medical Microbiology, 2, 133-137.

[32] Oranusi S, Dahunsi So, Owoso 00 and Olatile T. (2013). Microbial profiles of Hands, Foods, Easy contact surfaces and Food contact surfaces: A case study of a University Campus. Novus International Journal of Biotechnology \& Bioscience, 2(1), 30-38.

[33] Lynn M, Vivian OA and Wasa AA. (2013). The prevalence of bacterial organisms on toilet door handles in Secondary Schools in Bokkos L. G. A., Jos, Plateau Sate, Nigeria. IOSR Journal of Pharmacy and Biological Sciences, 8(4), 85-91.

[34] Augustino C, Asha L, Joel M, Alexanda M, Eliakunda M, Elisa M, Isaac M and Emma P. (2014). Determination of bacterial load and antibiotic susceptibility testing of bacteria isolated from students' toilets at Sokoine University of Agriculture, Morogoro, Tanzania. Journal of Health, Medicine and Nursing, Vol. 5.

[35] Ajayi A and Ekozien MI. (2014). Sensitivity Profile of Bacterial Flora Isolated From Bathroom. Elite Research Journal of Biotechnology and Microbiology, 2(1), 1 - 3.

[36] Mohammed SA, Tsaku PA, Nkene IH, Oti VB and Ekeleme IK. (2017). Plasmid-Mediated Resistance in Salmonella typhi Isolated from Door Handles in Nasarawa State, North-Central, Nigeria. Asian Journal of Biotechnology and Bioresource Technology, 1 (1), 1-12.

[37] Opere BO, Ojo JO, Omonighehin E and Bamidele M. (2013). Antibiotic Susceptibility and Plasmid Profile Analysis of Pathogenic Bacteria Isolated from Environmental Surfaces in Public Toilets. Transnational Journal of Science and Technology, 3(2), 22-30.

[38] Okonko IO, Soleye FA, Amusan TA, Ogun AA, Ogunnusi TA and Ejembi J. (2009). Incidence of Multi-Drug Resistance (MDR) Organisms in Abeokuta, Southwestern Nigeria. Global Journal of Pharmacology, 3(2), 69-80.

[39] Nahum GG, Uhl K and Kennedy DL. (2006). Antibiotics use in pregnancy and Lactation what is and is not known about teratogenics and toxic risks. Obstetrics and Gyneacology, 107 (5), 1120 -1138.

[40] Norwitz ER and Greenberg JA. (2009). Antibiotics in Pregnancy: are they safe? Review of Obstetric Gyneacology, 2(3), 135-6. 
[41] Ngwai YB, Nkene IH, Egan CA, Osabo PP and Envuladu EY. (2013). Minimum Inhibitory concentration of cephalosporin antibiotics for Fecal and Urinary Escherichia coli from University student in Keffi, Nigeria. Nsuk Journal of Sciences and Technology, 3, 1-2.

[42] Oteo J, Campos J and Baquero F. (2002). Antibiotic resistance in 1962. Invasive isolates of Escherichia coli in 27 Spanish hospitals participating in the European Antimicrobial Resistance Surveillance System (2001). Journal Antimicrobial Chemotherapy, 50, 945-952.

[43] Sherley M, Gardon DM and Collingnon PJ. (2004). Evolution of multi-resistance plasmids in Australia clinical isolates of Escherichia coli. Microbiology, 150, 1539- 1546.

[44] Piddock LJV. (2006). Clinically relevant chromosomally encoded multi drug resistance efflux pumps in bacteria. Clinical Microbiology Reviews, 19(2), 382-402.

[45] Depardieu F, Podglajen I, Leclercq R, Collatz E. and Courvalin P. (2007). Modes and modulations of antibiotic resistance gene expression. Clinical Microbiology Reviews, 20(1), 79-114.

[46] Leavitt A, Navon-Venezia S, Chmelnitsky I, Schwaber MJ and Carmeli Y. (2007). Emergence of KPC-2 and KPC-3 in carbapenem-resistant Klebsiella pneumoniae strains in an Israeli hospital. Antimicrobial Agents and Chemotherapy, 51(8), 3026-3029.

[47] Lockhart SR, Abramson MA, Beekman SE, Gallagher G, Riedel SR, Diekma DJ, Quinn JP and Doern GV. (2007). Antimicrobial resistance among Gram-negative bacilli as causes of infections in intensive care unit patients in the United States between 1993 and 2004. Journal of Clinical Microbiology, 45, 3352-3359.

[48] Akujobi CN and Ewuru CP. (2010). Detection of Extended Spectrum Beta-Lactamases in Gram Negative Bacilli from Clinical Specimens in a Teaching Hospital in South Eastern Nigeria. Nigerian Medical Journal, 51(4), 141146.

[49] Kamel NA, Aboshanab KM, Abouelwafa M and El-tayeb WN. (2013). Plasmid mediated extended spectrum betalactamase producing strains of enterobacteriaceae isolated from diabetic foot infections in Egypt. Archaeological Clinical Microbiology, 4(4), 1-8.

[50] Inwezerua C, Mendonça N, Calhau V, Domingues S, Adeleke OE and Da Silva GJ. (2014). Occurrence of extendedspectrum beta-lactamases in human and bovine isolates of Escherichia coli from Oyo state, Nigeria. Journal of Infectious Diseases in Developing Countries, 8(6), 774-779.

[51] Basma M, Hela H, Jihène J, Faouzia M, Nathalie G, Guillaume A and Adnene H. (2013). Molecular epidemiology of extended-spectrum beta-lactamase-producing Escherichia coli in Tunisia and characterization of their virulence factors and plasmid addiction systems. BMC Microbiology, 13(147), 2-9.

[52] El bouamri MC, Arsalane L, Zerouali K, Katfyd K, El kamouni Y and Zouhair S. (2015). Molecular characterization of extended spectrum b-lactamase-producing Escherichia coli in a university hospital in Morocco, North Africa. African Journal of Urology, 21, 161-6.

[53] Omar BA, Alfadel 00, Atif HA and Mogahid ME. (2013). Prevalence of TEM, SHV and CTXM genes in Escherichia coli and Klebsiella spp Urinary Isolates from Sudan with confirmed ESBL phenotype. Life Sciences Journal, 10(2), 191-195.

[54] Okeke IN, Aboderin OA, Byarugaba DK, Ojo KK and Opintan JA. (2007). Growing problem of multidrug-resistant enteric pathogens in Africa. Emerging Infectious Diseases, 13(11), 1640-1646.

[55] Shahi SK, Singh VK and Kumar A. (2013). Detection of Escherichia coli and Associated b-Lactamases Genes from Diabetic Foot Ulcers by Multiplex PCR and Molecular Modeling and Docking of SHV-1, TEM-1, and OXA-1 bLactamases with Clindamycin and Piperacillin-Tazobactam. PLoS ONE, 8(7), e68234.

[56] Sidjabat HE, Paterson DL, Adams-Haduch JM, Ewan L, Pasculle AW, Muto CA, Tian GB and Doi Y. (2018). Molecular Epidemiology of CTX-M-Producing Escherichia coli Isolates at a Tertiary Medical Center in Western Pennsylvania. Antimicrobial Agents and Chemotherapy, 62(8), 1-6.

[57] Bajpai T, Pandey M, Varma M and Bhatambare GS. (2017). Prevalence of TEM, SHV, and CTX-M Beta-Lactamase genes in the urinary isolates of a tertiary care hospital. Avicenna Journal of Medicine, 7(1), 12-16.

[58] Miriagou V, Carattoli A and Fanning S. (2006). Antimicrobial resistance islands: resistance gene clusters in Salmonella chromosome and plasmids. Microbes and Infection, 8, 1923-1930. 
[59] Winokur PL, Brueggemann A, DeSalvo DL, Hoffmann L, Apley MD, Uhlenhopp EK, Pfaller MA and Doern GV. (2000). Animal and Human Multidrug-Resistant, Cephalosporin-Resistant Salmonella Isolates Expressing a Plasmid-Mediated CMY-2 AmpC $\beta$-Lactamase. Antimicrobial Agents Chemotherapy, 44(10), 2777-2783.

[60] Carattoli A. (2003). Plasmid-Mediated Antimicrobial Resistance in Salmonella enterica. Current Issues in Molecular Biology, 5, 113-122.

[61] Helms M, Simonsen J and Molbak K. (2004). Quinolone resistance associated with increased risk of invasive illness or death during infection with Salmonella serotype Typhimurium. Journal of Infectious Disease, 190 (9), 1652-1654.

[62] Osman BÖ, Tosun I, Aydin F, Kiliç OA and Ertürk M. (2006). Carriage of Mobilizable Plasmid Mediated $\beta$ Lactamase Gene in Ampicillin-Resistant Escherichia coli strains with Origin of Normal Fecal Flora. Turkish Journal of Medical Sciences, 36 (5), 307-314.

[63] Yah SC, Eghafona NO, Oranusi S and Abouo AM. (2007). Widespread plasmids resistance transfers genes among Proteus species in diabetic wounds of patients in the Ahmadu Bello University Teaching Hospital (ABUTH) Zaria. African Journal of Biotechnology, 6(15), 1757-1762.

\section{How to cite this article}

Tsaku PA, Ibrahim T, Nkene IH, Abimiku RH, Ishaleku D, Pennap G and Ngwai YB. (2019). Molecular diversity of multiresistant and extended-spectrum beta lactamase-producing Escherichia coli from door handles in Lafia, central Nigeria. GSC Biological and Pharmaceutical Sciences, 8(1), 35-45. 